\title{
Könyvszemle
}

\section{Purebl György: \\ Alacsony intenzitású pszichológiai intervenciók a mindennapi orvosi gyakorlatban}

(Low intensity psychological interventions in everyday medical practice)

Oriold és Társai Kiadó, Budapest, 2018

116 oldal, $2100 \mathrm{Ft}$

ISBN 978-615-5443-84-8

Purebl György könyve rendhagyó és nagyon modern tankönyv. Rendhagyó azért, mert rövid, mindössze 116 oldal. S nagyon modern, mert már a terjedelem is figyelembe veszi, hogy a mai olvasónak nagyon kevés ideje jut az olvasásra. Különösen a gyakorló szakemberekre igaz ez, akik gyorsan szeretnék megtudni a lényegi információkat, s nincs idejük arra, hogy hosszas elméleti fejtegetéseket olvassanak el akkor, amikor egy nagyon konkrét gyakorlati feladatot kell megoldaniuk. Ez a könyv a számukra készült, s maximálisan figyelembe veszi az időhiányban szenvedő diákok és szakemberek igényeit.

Mindannyian, akik egyetemen tanítunk, ismerjük a diákok azon szokását, hogy 5-600 oldalas tankönyveket 80-100 oldalas jegyzetekre rövidítenek le. Ha ezt diákok teszik, az sokszor katasztrofális eredményekkel jár, hiszen ők nem mindig tudják a lényeget jól kiemelni. Purebl György, aki maga is sok évtizedes tapasztalattal rendelkezó egyetemi docens, elvégezte ezt a munkát a diákok helyett. Ố rövidítette le a könyvet, s oktatói tapasztalata, valamint pszichiátriai-pszichoterápiás szakértelme a biztosíték, hogy így sem maradt ki semmi lényeges. Az alacsony intenzitású pszichológiai intervenciókat (low intensity psychological interventions, a továbbiakban LIPI) úgy mutatja be, hogy a leggyakoribb problémákra koncentrál, amelyekkel egy szakember naponta foglalkozik. Kimaradnak így a könyvból a csak ritkán használt módszerek, valamint az online LIPI ismertetése is. A szerző úgy írta a könyvet, hogy az egy mobiltelefonon is megnézhető, lapozható legyen. Megemlítendő, hogy a gyönyörú grafikák, ábrák, színek szinte esztétikai élvezetté teszik a lapozgatást.

A könyv 10 fejezetból áll. Minden fejezet egy esetleírással kezdődik, amely bevezeti a megoldandó problémát, s egy problémamegoldó feladat- 
tal végződik, amely a tudás ellenőrzésére szolgál. A könyv végén külön fejezet tartalmazza a problémamegoldó feladat megoldásait, magyarázatokkal kísérve. Mindez nagyban segíti a kötetben tárgyalt módszerek gyakorlatba való átültetését. A kötet nagy előnye az is, hogy az egyes fejezetei önálló blokkok, vagyis nem tételezik fel az előző fejezet ismeretét. Amire éppen szükség van, az könnyen megtalálható, s az olvasott fejezet önmagában is értelmezhetó.

Az 1. fejezet a LIPI definícióját, alapvető módszereit tartalmazza, a 2. fejezet pedig a segítő beszélgetés alapkészségeiről szól. A 3. fejezet a betegekkel foglalkozó orvos szorongáscsökkentési lehetőségeit mutatja be. A 4. fejezet az élethelyzeti nehézségek kapcsán a problémamegoldó módszereket ismerteti. Az 5. fejezet a motivációs interjúról szól, hiszen nagyon sok esetben a gyógyulással kapcsolatos motiváció megteremtése a későbbi terápiás siker kulcsa. A 6. fejezet a pszichológiai elsősegély módszereit tárgyalja, amelynek alkalmazására súlyosan negatív életesemény, akut stressz kapcsán van szükség. A 7. fejezet a depresszió megelőzéséről, és az enyhe depressziós tünetek esetén alkalmazható módszerekról szól. A 8. fejezet a krónikus fájdalmakkal való megbirkózás pszichológiai módszereit mutatja be. A 9. fejezet a szexuális zavarokkal kapcsolatos tanácsadás során használható, végül a 10. fejezet az alvási nehézségek esetében alkalmazható módszereket ismerteti.

A könyv használhatóságának a szemléltetésére hadd mutassam be részletesebben a 7. fejezetet, amely a rosszabb hangulat vagy enyhe depressziós tünetek fennállása esetében alkalmazható egyszerú technikákról szól. A fejezet - a minden fejezet elején megtalálható - esetleírással kezdődik, amelyben a 47 éves Róbert magasvérnyomás-betegségben szenved, és vérnyomása ingadozása miatt keresi fel a háziorvosát. A beszélgetés során kiderül, hogy Róbert munkahelyén problémák léptek fel, ezért sokszor be sem kell mennie, s napokig teng-leng otthon, miközben emiatt búntudata van. De semmihez nincs kedve, fél munkahelye elvesztésétől. A családorvos, felismerve, hogy Róbert az igazi, klinikai depresszióba való becsúszás határán van, megtanítja őt néhány egyszerú módszerre, amellyel megelőzhető, hogy depresszióssá váljon. Arra kérte Róbertet, írjon egy öröméletrajzot, vagyis vegye számba, hogy gyerekkorától mostanáig melyek voltak a kedvenc örömszerző tevékenységei. Ezeket ismét elkezdve Róbert elkezdett többet mozogni, ezáltal kicsit sikerült lefogynia, ingadozó vérnyomása is beállíthatóvá vált. Jobb hangulata aktívabbá tette, s új munkahelyet is talált magának. A családorvos által végzett pszichológiai beavatkozás egy 6 hetes időszakban 5 × 20 percet vett igénybe, s rengeteg késóbbi problémát akadályozott meg. Eme esetismertetés után következik a depressziómegelőzés kis intenzitású technikáinak a leírása, mint amilyen a viselkedésaktiválás, a pozitív élményekre való fókuszálás elősegítése, illetve a testmozgás előírása. 
A fejezet végén található problémamegoldó feladatok átgondolásával és a megoldások megtekintésével pedig megtudhatjuk, hogy mely célok alkalmasak a viselkedésaktivációs programba való beépítésre, és melyek nem.

Egészében véve Purebl György könyve nagyon konkrét, rendkívül tömör, ugyanakkor igen olvasmányos. Mindenkinek ajánlom, aki egyszerú módszereket szeretne tanulni pszichológiai hátterú problémák megoldása érdekében.

Kovács József

E-mail: kovacs.jozsef@med.semmelweis-univ.hu 